\title{
Comparison of Microbiological Water Quality and Chlorine Level Between Adult Public Swimming Pool and Baby Public Swimming Pool in Klang Valley, Malaysia.
}

Shahida Abd. Zamzami

Management \& Science University (MSU)

Muhammad Naim Bin Rosli ( $\square$ muhammadnaim.rosli@gmail.com )

Management \& Science University (MSU) https://orcid.org/0000-0002-0920-6641

\section{Research Article}

Keywords: Microbial Quality, Physicochemical, Safety, Swimming Pools, Bacteriological

Posted Date: December 1st, 2020

DOI: https://doi.org/10.21203/rs.3.rs-108056/v1

License: (9) (1) This work is licensed under a Creative Commons Attribution 4.0 International License. Read Full License 


\section{Abstract}

Background: Swimming becomes one of the favourite sports in Malaysian due to the health benefits, for essential skills. ). The public swimming pool not only from an adult but there are created as well for children, so most of the public swimming pool also provided a baby swimming pool.

Objective: The purpose of this research to compare the microbiological water quality and chlorine level between the adult public swimming pool and baby public swimming pool in Klang Valley.

Methodology: 21 water sample from public swimming pools include hotel, apartment and public swimming pool in Lembah Klang, Malaysia was collected. The water samples collected in sterile bottles $(30 \mathrm{ml})$. Physicochemical parameters determine by using standard instruments and methods (rainbow model 78), and the presence of the colony was using a heterotrophic plate count (HPC).

Result: From heterotrophic plate count result shown out of 21 swimming pool for adult and 21 swimming pool for baby, 19.1\% did not follow the World Health Organization (WHO), HPC. The microbiological quality (mean colony count) between baby and adult pool, there were slight differences of at $0.24 \%$. The baby pool shows the higher value at of colony count at $111 \pm 197.334$ compared with adult pool at $87.095 \pm 149.543$. The independent $t$-test showed there is no significant between these groups with a p-value for at 0.65 ( $>0.05)$. For chlorine level, baby pool showed $47.6 \%$ swimming pools follow standard chlorine level and for an adult pool, $42.9 \%$. Comparing between two groups, baby pools show higher value with of chlorine at $1.581 \pm 1.369$ while adult pool at $1.414 \pm 1.293$. The $p$-value for both as analyzed by independent t-test shows $0.694(>0.05)$, which is not significant.

Conclusion: The study recommends improvement in personal hygiene of swimmers, adequate disinfection of the pools and enforcement of standards by the government.

\section{Introduction}

In this modern era, people recognized swimming as a beneficial recreational activity for the health, skills and one of the popular sport among Malaysian. Moreover, swimming is an artificially enclosed body of water intended recreation or other bathing activities that involve swimmer (Perkins, 1988). Swimmers background come from the adult and children, most of the public swimming pool provide with baby swimming pool (baby pool) that usually differs from the adult swimming pool in term of depth and size. Most of the people in the urban country choose the swimming pool rather than the beach or waterfall might be due to its safety and cleanness. However, the swimming pool water can be contaminated by variety pathogenic microorganisms which may be obtained via several ways for example from excretion products from the swimmers, airborne contamination, or low sanitary status of the swimming pool itself (Environmental Protection Agency (EPA), 2011). In deep, swimmers one of the leading causes swimming pool water will be contaminated, it may come from swimmer secretion such as saliva, blood, urine, stool, swimwear, skin tissue, sweat, and cosmetics produces (deodorant, make-up, sunscreen, etc.). This contaminated water leads to a variety of waterborne disease including diarrhoea, skin rashes, ear infection, and upper respiratory infection particularly when the swimmer's head was inundated, or the swimmer accidentally swallowed the contaminated water (WHO, 2004; Agbabiaka, 2010).

The swimming pool needs proper sanitation to maintain the hygienic regulation of swimming pool by WHO and to ensuring the safety condition of the swimming pool toward the public. The goal of sanitation is usually to prevent the spread of diseases and pathogens between users. (Totkova et al., 1994). According to Agbabiaka, (2010) the water swimming pool safety, especially toward cleanness and sanitization aspect should be one of the most important things taken as count toward public since it impacts the swimmer health. Some alternative pool system to maintain sanitation include use saltwater or UV treatment system.

Recreational water illnesses (RWIs) or waterborne disease are one of the illness which causes by germs spread by swallowing, breathing in mists or aerosols of, or having contact with contaminated water in swimming pools, hot tubs, water parks, water play areas, interactive fountains, lakes, rivers, or oceans (CDC, 2008). It defined as any illness coming from the consumption of or water contaminated with producing agents including bacteria, fungi, viruses, parasites, and their products as well toxic substances which not a microbial origin. It is one of the important factors toward public health community problem, which caused a big impact on economic and trade in the developing country, especially in Malaysia. (Sharifa Ezat et al., 2013) Chlorine level is one of the methods used to check the cleanness of swimming pool water. The chlorine concentration in pool water might reduce due to urine, stool, sweat, and any discharge from swimmers' bodies, which may lead to less effectiveness to pathogenic bacteria. Furthermore, according to WHO (2006), droplets or mists come sunlight might free chlorine concentration. That is why the free chlorine concentration must be routinely tested. It is important for chlorine level to be check at least once a day to make sure it at the standard range between 1.5 to $3 \mathrm{ppm}(\mathrm{WHO}, 2006)$ to avoid formation or growth of pathogenic bacteria in the swimming pool. The chlorine levels bather load is usually much higher at $3-5 \mathrm{ppm}$, but if the chlorine levels between 5-10 
ppm are still safe to swim. As the side effect swimmers may exposure and provoke potentially skin and eye irritation, lung irritation and asthma. The objective of this study compares the microbiological water quality and chlorine level between the adult public swimming pool and baby public swimming pool in Klang Valley.

\section{Methodology}

\section{Study Design}

Quantitative research with correlation was used in this study since it experimental research establish with a relationship microbial quality and chlorine level between two groups which are the baby swimming pool and adult swimming pool. The quantitative cross-sectional study was carried across the Klang Valley, Malaysia area. A random sampling method had been used since hard numerical data and analysis had ben use to prove the effectiveness of making the decision. This study does not have any time dimension since its dependence on the quantity of swimming pool.

\section{Study Area}

This study had been conducted in several randomly public swimming pools including apartments, hotels and municipal across Klang valley Malaysia. Klang Valley is an urban conglomeration in Malaysia that is centred in Kuala Lumpur, with $2900 \mathrm{~km}$ wide. This area had been selected since it one of the developed states in Malaysia with a population of about 7.53 million peoples in 2015 (Jabatan perangkaan Malaysia, 2015). It is one of the popular states for leaving and tourist attraction.

\section{Water sample collection}

The sterile $30 \mathrm{ml}$ universal bottle was used to collect the water sample. Then, the 21 water sample was collected from different adult and baby municipal, hotels and apartments public swimming pool around Klang Valley. All the water samples were taken $30-50 \mathrm{~cm}$ deep from the water surface of the swimming pool according to the American Public Health Association (APHA, 1998) sampling guidelines on the standard operating procedures for examination of water and wastewater. The water sample was then brought to the lab for microbiological quality analysis within 8 hours from the time it is collected.

\section{Chlorine level analysis}

The chlorine level analysis of the water swimming pool water had been testing using a Pentair pool water Test Kits (DPD kits). This test includes chlorine or bromine test solution $1, \mathrm{pH}$ test solution 2, acid domain and total alkalinity solution 3 , Chlorine neutralizer solution 4 , Total Alkalinity test solution 5, and consist of 2 Chamber Comparator, but we've been used for chlorine test only. The features for chlorine test in this test kit consist of free and total chlorine; $0.5 \mathrm{ppm}-3.0 \mathrm{ppm}$. The chlorine test vial is filled with pool water to the line, and then solution 1 was added 5 drops and the cap was replaced and swirling by thoroughly mixed. The data was recorded.

\section{Microbiological quality analysis}

Samples were diluted by serial dilution method as described by the American Public Health Association (APHA, 1985) and heterotrophic plate count (HPC) using a standard plate count method by Guidelines for safe recreational water environments (WHO, 2006). One milliliters of the water sample was cultured in nutrient agar then it was incubated for 24 hours for $37^{\circ} \mathrm{C}$. Mean of heterotrophic plate count were obtain and calculated to gain a colony-forming unit per ml sample.

\section{Statistical analysis}

The t-test analysis was used to compare the two groups of mean using Statistical Package for the Social Sciences (SPSS) version 24.0 (SPSS, RRID:SCR_002865) and Microsoft Excel 2010 (Microsoft Excel, RRID:SCR_016137). The t-test ware used to, as a result, is an independent variable with two levels of the variable. The dependent variable for this study is in numerical as it compares the mean of chlorine level and means of the bacterial count.

\section{Results And Analysis}

Form the total of 21 water sample from the adult swimming pool and baby swimming pool, there is 4 sample from the adult swimming pool, and four water sample form baby swimming pool showed had a heterotrophic plate count (cfu/ml) more than $200 \mathrm{cfu} / \mathrm{ml}$-the result as per shown in figure 1 . 
The mean microbiological analysis is shown in figure 2 . The study had shown mean heterotrophic plate count baby swimming pool shows the value at 111 (SD =197.334) and mean heterotrophic plate count for adult swimming pool shows at 87.095 (SD=149.54).

An independent-samples t-test was conducted to compare heterotrophic plate count (cfu/ml) adult swimming pool and heterotrophic plate count (cfu/ml) baby swimming pools conditions. This table 1

Table 1: Independent t-test of mean heterotrophic plate count (cfu/ml) adult and baby swimming pools

\begin{tabular}{|c|c|c|c|c|c|c|c|c|}
\hline & & \multicolumn{2}{|c|}{$\begin{array}{l}\text { Levene's Test for Equality of } \\
\text { Variances }\end{array}$} & \multicolumn{5}{|c|}{ t-test for Equality of Means } \\
\hline & & $F$ & Sig. & $t$ & df & $\begin{array}{l}\text { Sig. } \\
(2- \\
\text { tailed) }\end{array}$ & $\begin{array}{l}\text { Mean } \\
\text { Difference }\end{array}$ & $\begin{array}{l}\text { Std. Error } \\
\text { Difference }\end{array}$ \\
\hline \multirow[t]{2}{*}{ value } & $\begin{array}{l}\text { Equal variances } \\
\text { assumed }\end{array}$ & 1.119 & 0.297 & -0.457 & 40.000 & 0.650 & -25.238 & 55.246 \\
\hline & $\begin{array}{l}\text { Equal variances not } \\
\text { assumed }\end{array}$ & & & -0.457 & 37.333 & 0.650 & -25.238 & 55.246 \\
\hline
\end{tabular}

From table 1, an independent-samples t-test was conducted to compare mean heterotrophic plate count (cfu/ml) adult and baby swimming pools. There was no significant difference in the heterotrophic plate count (cfu/ml) adult swimming pools (M=87.095, SD=197.334) and heterotrophic plate count ( $\mathrm{cfu} / \mathrm{ml})$ baby swimming pools $(M=111, \mathrm{SD}=197.334)$ conditions; $\mathrm{t}(40)=-0.457, \mathrm{p}=0.650$. It shows that is no significant value (2-tailed) which is p-value is 0.650 for both groups of the mean heterotrophic plate count with a $95 \%$ confidence interval.

From the total of 21 water sample form the adult swimming pool and baby swimming pool, there is about 12 adult swimming pool and 11 baby swimming pool chlorine level shown less than $1.5 \mathrm{ppm}$. Result as per shown in figure 3.

The mean chlorine level analysis is shown in figure 4. The study had shown mean chlorine level adult swimming pool shows at 1.414 (SD $=1.369$ ) and mean chlorine level for baby swimming pool shows at 1.581 (SD=1.293).

Table 2: Independent t-test of mean chlorine level (ppm) between the adult swimming pool and baby swimming pool.

\begin{tabular}{|c|c|c|c|c|c|c|c|c|}
\hline & & \multicolumn{2}{|c|}{$\begin{array}{l}\text { Levene's Test for Equality of } \\
\text { Variances }\end{array}$} & \multicolumn{5}{|c|}{ t-test for Equality of Means } \\
\hline & & $\mathbf{F}$ & Sig. & $\mathrm{t}$ & df & $\begin{array}{l}\text { Sig. } \\
(2- \\
\text { tailed) }\end{array}$ & $\begin{array}{l}\text { Mean } \\
\text { Difference }\end{array}$ & $\begin{array}{l}\text { Std. Error } \\
\text { Difference }\end{array}$ \\
\hline \multirow[t]{2}{*}{ value } & $\begin{array}{l}\text { Equal variances } \\
\text { assumed }\end{array}$ & 1.518 & 0.225 & -0.396 & 40 & 0.694 & -0.1667 & 0.4211 \\
\hline & $\begin{array}{l}\text { Equal variances not } \\
\text { assumed }\end{array}$ & & & -0.396 & 39.869 & 0.694 & -.1667 & 0.4211 \\
\hline
\end{tabular}

From table 2, an independent-samples t-test was conducted to compare mean chlorine level (ppm) between the adult swimming pool and baby swimming pool. There was no significant difference in the mean chlorine level (ppm) adult swimming pools $(M=1.414, S D=1.369)$ and mean chlorine level (ppm) baby swimming pools at $1.581(\mathrm{SD}=1.293$ ) conditions; $\mathrm{t}(40)=-0.396, \mathrm{p}=0.694$. It shows that is no significant value (2-tailed) which is p-value is 0.694 for both groups of the mean heterotrophic plate count with a $95 \%$ confidence interval.

From this table, it shows that significant (2-tailed) which is p-value is 0.694 for both groups of the mean chlorine level with a $95 \%$ confidence interval.

\section{Discussion}


From the results 21 public swimming pool water sample which was collected from apartments, hotels and municipal in Klang Valley, there were about four swimming pools (19.1\%) from adult and baby swimming pools and which did not follow mean heterotrophic plate count provided by WHO. According to WHO (2006), the standard bacterial count in pool water must less than $200 \mathrm{cfu} / \mathrm{ml}$. The high colony count in the swimming pool water may probably come from the source of contaminated water supply. There is a possibility due to ineffectiveness treatment or disinfectant of the swimming pools. There will be an increase in bacterial load after the pools were used by the swimmer. It supported by Indabawa (2015) mention that swimmer tends to increases the organic matter in the pool water by shedding the bacteria from faecal and non-faecal sources. The chlorine level resulted as $47.6 \%$ of baby swimming pool out of 21 baby swimming pools and for adult swimming pool, shows $42.9 \%$ were following the standard chlorine level provided by WHO. The standard range for chlorine level of swimming pool water in-between 1.5 to 3 ppm (WHO, 2006). The chlorine level in the swimming pool water could be reduced because of the water contamination by an unwanted substance such as urine, stool, sweat, and dirt from the swimmers' body as it will be broken down to free available chlorine. The chemical reaction between bacteria and germs with chlorine will use reduce the chlorine level. Moreover, According to Centers for Disease Control and Prevention (CDC), the sunlight creating droplets or mists from the water will reduce the chlorine level as a recommendation from CDC free chlorine concentration must be routinely tested at least twice a day (CDC, 2016).

From the 21-swimming pool water sample collected, mean heterotrophic plate count for baby swimming pool shown at $111 \pm 197.3339$ (56\%) and for the adult public swimming pool at $87.09524 \pm 149.5431$ (44\%) which is lower than the baby pool. There were slightly different, about $0.24 \%$ between these two groups. The p-value for both was analyzed by independent t-test shown a result of 0.65 ( $>0.05$ ) which there is no significant between the mean heterotrophic plate count for adult swimming pool and mean heterotrophic plate count for the baby swimming pool. The similar result was shown by Oloruntoba et al. (2012) that shows there is no significant in bacterial count between two groups. The heterotrophic plate count from the baby pool showed higher value could result from bacterial transmission from the diapers worn by the baby. The diapers have an ability to release most parasite-micro sized particles within 5 minutes, hitting the water.

As for mean chlorine level, the results obtained from the baby swimming pool shows at 1.580952 \pm 1.369261 (52.8\%) and adult swimming pool $1.414286 \pm 1.292943$ (47.2\%). This shows slight differences in mean chlorine between these two groups. Although there were differences between these two groups by $0.0016 \%$, p-value independent t-test shows 0.694 (>0.05), which is not significant. Similar result by Agbabiaka, (2010) in Nigeria shows there is no significant in chlorine level between two groups. The chlorine level in the baby pool showed higher value might be because the baby pool is rarely used, and maybe because of the amount of chlorine pour in the water is not properly calculated. There is a possibility that some of the swimming pool have a difference in depth give a different concentration.

\section{Conclusion}

In conclusion, from the finding that some of the swimming pools did not comply with the regulation from WHO and EPA standard for recreational waters in terms of the effectiveness of treatment of swimming pools and confirmed the aesthetic unsuitability of the swimming pools. As we can see from this findings, there is a little difference in microbiological quality and chlorine level between the adult public swimming pool and baby public swimming pool, but both parameters did not shows significant from the analysis. It is recommended that health authorities should regularly monitor the pools for compliance with regulations and frequency of treatment of these pools should also be intensified.

\section{Declarations}

\section{Ethics Approval and Consent to Participate}

This research did not involve any human participation.

\section{Human and Animal Rights}

No Animals or Humans were used for these studies.

\section{Conflict of interest (COI)}

The paper did not have any conflict of interest.

\section{References}

1. Agbabiaka T.O. (2010), Biological and Environmental Sciences Journal for the Tropics 7(4) pp 108-112. 
2. American Public Health Association (APHA, 1998). Standard Methods for the Examination of Water and Wastewater. 20th ed., APHA, Washington, D.C.

3. Centres for Disease Control and Prevention (CDC), (2008) Violations identified from routine swimming pool inspections - selected states and countries, United States, 2 MMWR Morb Mortal Wkly Rep. 2010;59(SS19):582-587

4. Centres for Disease Control and Prevention (CDC) (2016), Your Disinfection Team: Chlorine \& pH, Protection against Recreational Water Illnesses (RWIs). http://www.cdc.gov/healthyswimming/fecal_response.htm

5. Environmental Protection Agency (EPA) (2001). Bacteria water quality, standards for recreational waters (Fresh and marine waters) pp. 123-145.

6. Indabawa I.I., (2015) Assessment of Microbiological and Physico-Chemical Quality of Some Swimming Pools within Kano Metropolis, Kano Nigeria, rd International Conference on Biological, Chemical \& Environmental Sciences (BCES-2015) Sept. 21-22, 2015 Kuala Lumpur (Malaysia), pg 42-46

7. Jabatan perangkaan Malaysia. (2015). the Malaysia Economic Statistics Time Series 2015.

https://www.dosm.gov.my/v1/uploads/files/4_Portal\%20Content/1_About\%20us/7_AnnualReport/Laporan_Tahunan_2015_D0SM.pdf

8. Perkins P.H. (1988). Applied science, Elsevier, London pp. 257-296.

9. Sharifa Ezat, W. P., Netty, D., \& Sangaran, G. (2013). Paper review of factors, surveillance and burden of foodborne disease outbreak in Malaysia. Malaysian Journal of Public Health Medicine, 13(2).

10. Totkova A. (1994) Helminth and protozoal findings in the water of school swimming's 43(3) 130-136

11. World Health Organization. (2004). Guidelines for drinking water quality.3rd edition. Geneva.

12. World Health Organization. (, 2006). Guidelines for safe recreational water environments: Volume 2. Swimming pools and similar environments. World Health Organization (Vol. 2). Switzerland.

\section{Figures}

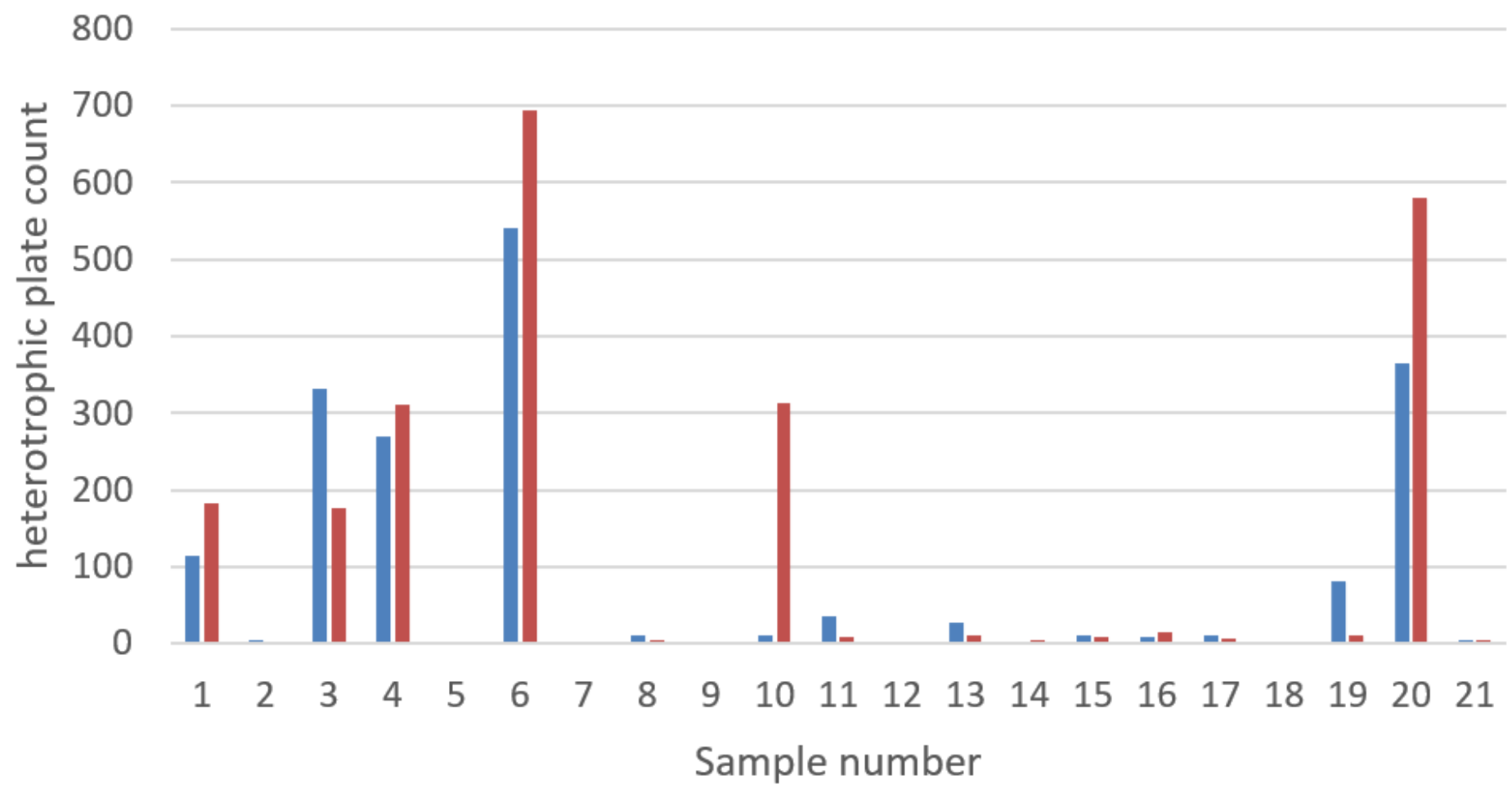

Figure 1

microbiological analysis means heterotrophic plate count (cfu/ml) between adult and baby swimming pool 
MEAN COLONY COUNT

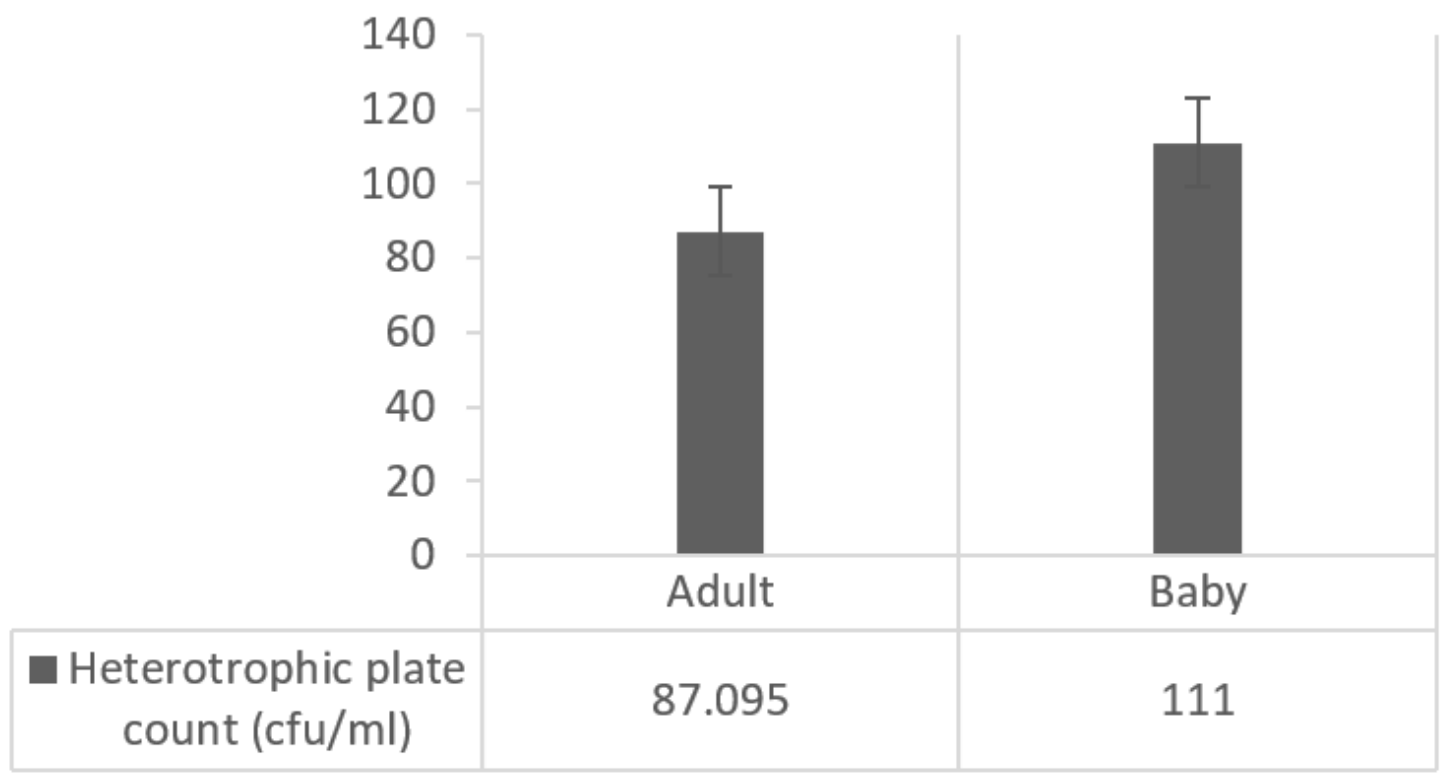

Figure 2

Means heterotrophic plate count (cfu/ml) between adult and baby swimming pool.

\section{Chlorine level}

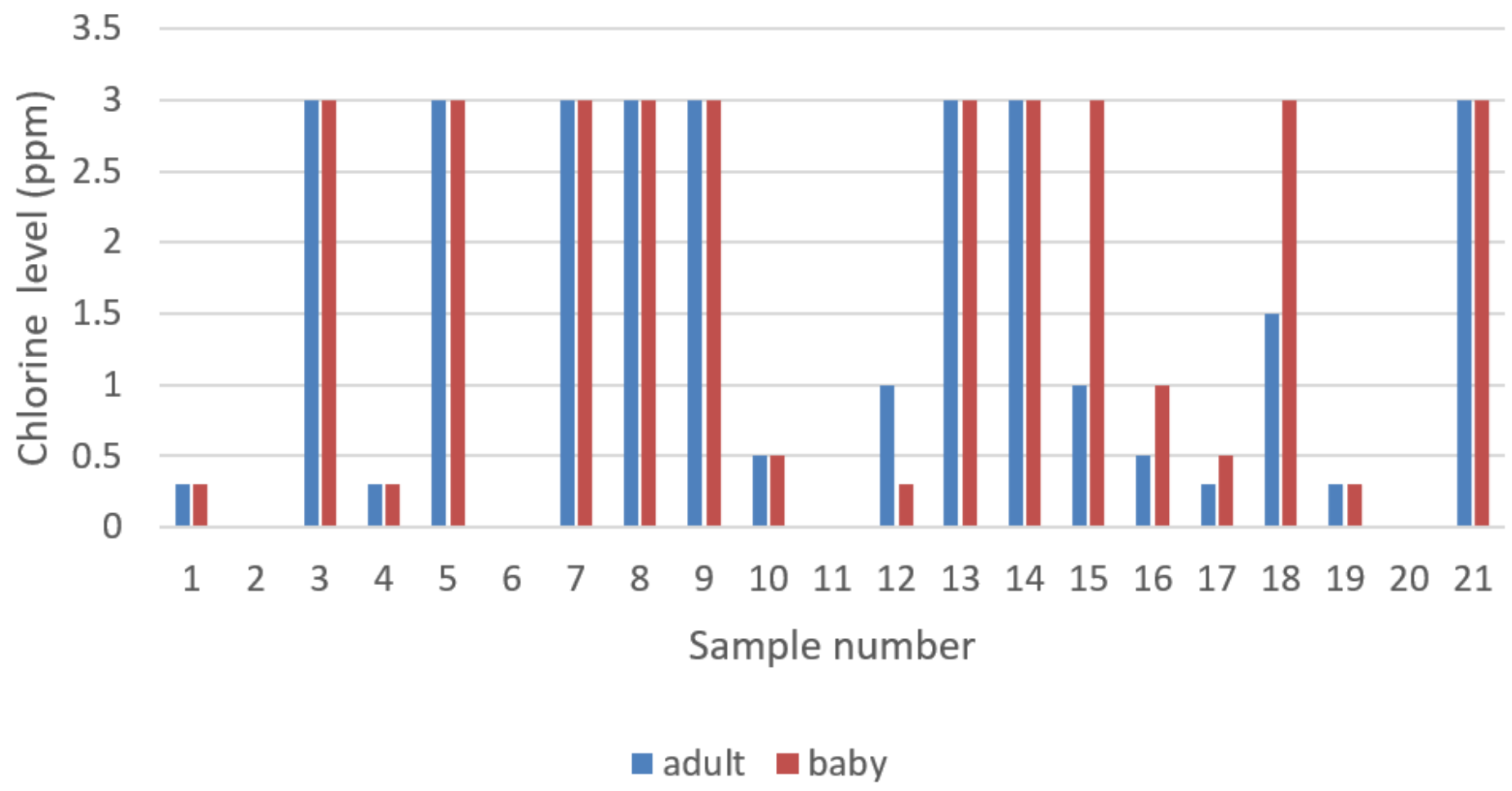

Figure 3

Chlorine level (ppm) between the adult swimming pool and baby swimming pool 


\section{Mean chlorine level}

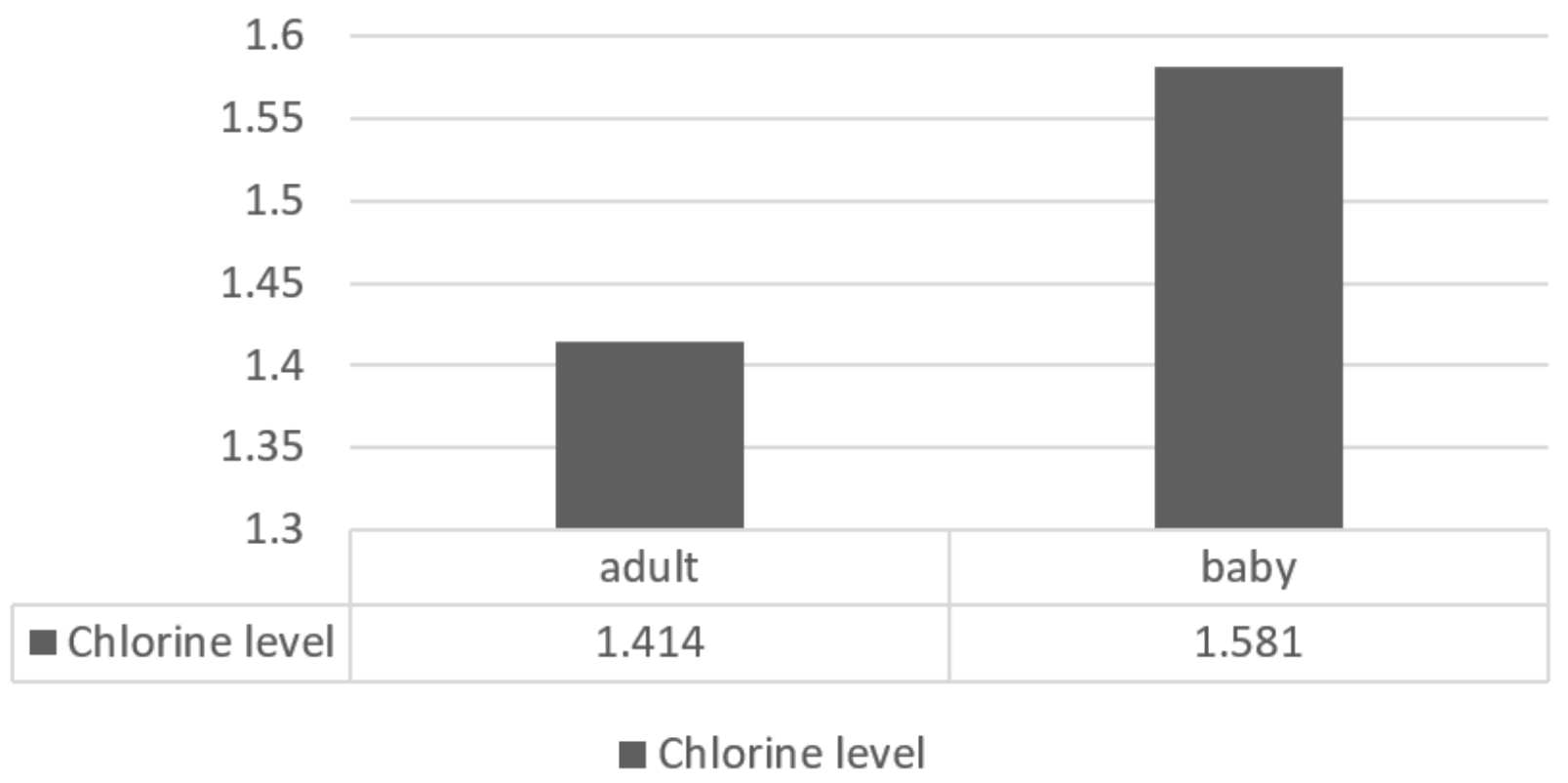

Figure 4

graph means of chlorine level between adult and baby pool 